\title{
Review: assessment of the doable utilisation of dendrochronology as an element tracer technology in soils artificially contaminated with heavy metals
}

\begin{abstract}
In the modern industrial world, there are many mineral resources of such emissions from metal exploitation to below-ground extraction. Tree-ring analysis or dendrochronology is both an old and a modern science. Tree rings are bound to the process of secondary radial growth of the xylem. Woody monocotyledons never form tree rings due to the absence of secondary xylem. To reconstruct trace metals contamination history, annual growth rings should be studied first as the potential archive of these lost elements in the wide environment. In recent decades, it has become a science with a broad range of applications such as global climate change, canopy process decline, the carbon cycle, and many others. We aimed to give an overview of the main features of metals transporters in plants drawing on information from previous studies in a wide variety of organisms. Here, we traced the mechanism of the heavy metals bioaccumulation in different biological systems as the phytostabilization (immobilization in plant roots), dendroremediation (growing trees in polluted soils), and hyperaccumulation (exceptional metal concentration in plant shoots). Further, this review highlights better understanding of the bioaccumulation and transportation of the metals in the variety of organisms and contaminated ecosystems showing the dendrochronology viable role as sustainable and eco-friendly bioremediation technology. Our findings have also referred to the micronutrients for plant metabolism which are existed to satisfy the requirements of cellular metabolism to protect cells from toxic effects. As a result, we consider tree-ring an indicator for pollution with transition metals especially for the roots in contaminated soils. This technique can monitor historical changes in atmospheric trace metals deposition and mobilisation in soil.
\end{abstract}

Keywords: modern industrial world, emissions, bioremediation, cellular metabolism, pollution, mobilisation
Volume 2 Issue I - 2018

\author{
Loai Aljerf,' Ala Eldin Choukaife ${ }^{2}$ \\ 'Department of Life Sciences, University of Damascus, Syria \\ ${ }^{2}$ Department of Life Sciences, Syrian Private University, Syria
}

Correspondence: Ala Eldin Choukaife, Department of Life Sciences, Faculty of Dentistry, Syrian Private University, Damascus, Syria, Tel +963-94 4490 I27,

Email chokala60@yahoo.com

Received: August 18,2017 | Published: January 10,2018

\section{Introduction}

During the past decade, considerable concern has been expressed by environmental scientists over the increasing levels of a range of toxic elements in the environment. Among the most potentially hazardous are the so-called 'heavy metals', a term applied to cover a range of transition elements, including copper, zinc and nickel and other elements such as cadmium, mercury and lead. Acutely toxic levels of these metals rarely occur, but ample evidence is available which demonstrates their increasing occurrence in many organisms.

There is clearly a need to investigate the rates of input of heavy metals into biological systems, and their subsequent behaviour within such systems. Therefore, to produce a clearer understanding of the long-term effects of heavy metals, we must be in possession of information relating to both the rate--and hence the absolute quantity-of heavy metals deposited within a specified system. Shotyk et al. have produced such data for lead deposition in blanket bog peat. Here, analysis of peat cores, combined with palynological analysis, was used to produce values for ambient lead levels extending over several centuries. Dating the age of a particular layer of peat presents few problems to experienced palyonologists, and in view of this the analysis of peat layers may be of considerable use in producing heavy metal pollution histories.

However, not all areas subjected to such metal deposition possess the anaerobic, waterlogged conditions which favour peat production. In such cases, the analysis of soil cores may be rendered meaningless by many factors: human activity, the activity of soil organisms or the incorporation of naturally-occurring mineralised rock into the soil. In such circumstances, alternative techniques must be devised to produce pollution histories. Sharma et al. ${ }^{2}$ Brink et al. ${ }^{3}$ Méndez et al. ${ }^{4}$ have attempted to describe changes in ambient lead levels by analysis of the lead levels in calcified human tissues of known ages. Miquel and Bungartz ${ }^{5}$ have produced metal pollution histories by analysis of dated herbarium specimens of various bryophytes.

Both these techniques have the advantage of measuring biologically-available metal levels, but their usefulness is restricted, especially in terms of producing wide-ranging pollution histories on a readily repeatable basis.

Clearly the concept of pollution histories of biologically-available heavy metals is attractive, and, in some respects, essential, in the study of long-term behaviour of heavy metals in biological systems. A suitable organism for such long-term surveillance must satisfy the following criteria. It must be long-lived, static, must possess mechanisms of metal uptake which can be identified and quantified, must grow on a regular seasonal basis, producing easily dated annual growth increments, and be easily and non-fatally sampled. Trees satisfy all these criteria.

\section{Previous tree-ring studies}

The science of tree-ring analysis is a wide-ranging field, with applications too numerous and well known to document. During the 
last three years, proposals have been made that chemical analysis of successive annual growth rings may be utilised in determining heavy metal pollution patterns. Observations by Jones et al. ${ }^{6}$ on the lead content of different growth rings of American elm (Ulmus americana) represent the first attempt at the production of a pollution history. Subsequently, more detailed investigations have been reported by Napierała-Filipiak et al. ${ }^{7}$ and Crispino and de Lima. ${ }^{8}$

The initial observations of Jaskowska-Lemańska and Wałach ${ }^{9}$ and Racko et al. ${ }^{10}$ demonstrated distinct increases in lead content of the more recently formed annual growth rings, which could be related to parallel increases in traffic density. Bellis et al. ${ }^{11}$ Kosobrukhov et al. ${ }^{12}$ Lukowski \& Wiater ${ }^{13}$ and Yeston, ${ }^{14}$ have produced more detailed studies on lead content of annual growth rings. Distinct patterns in lead content were observed, and the authors claimed that changes in lead levels could be correlated with changes in traffic density, and even changes in levels of lead anti-knock in petrol marketed possibly during the Second World War. The findings of these two teams are in marked contrast to that of Szopa et al. ${ }^{15}$ Here, no decline in lead content of the annual growth rings of white oak (Quercus alba) was observed following the abandonment of a highway in close proximity to the sampled trees. Thus far no reports exist of the production of a pollution history for any other metal using this technique.

\section{Pathways of metal uptake}

Three direct pathways exist for heavy metal entry into trees. These are: (1) uptake from the soil via the roots, with subsequent transport into woody tissue via the transpiration stream; (2) foliar uptake, with subsequent export from the leaf via the phloem, followed by lateral movement from this tissue into the xylem; (3) direct deposition onto stem surfaces followed by lateral movement across the bark and into the wood.

\section{Root uptake}

The entry or re-entry of heavy metals into the plant via the roots will be regulated to a certain extent by edaphic factors. The degree of regulation is dependent upon the soil-type involved, but, in general, soils of high $\mathrm{pH}$ will tend to immobilise larger amounts of heavy metals than soils of a lower $\mathrm{pH}^{16,17}$ If a soil is deficient in certain macro-nutrient elements, increased quantities of heavy metals may be available for uptake. Cui et al. ${ }^{18}$ reported that uptake of lead by rye grass is enhanced by a sulphate-deficient medium, and elements which possess insoluble phosphates may be taken up more readily in conditions of phosphate deficiency.

Whilst these edaphic factors are of considerable importance, biological factors may be equally important in regulating the quantities of certain elements which can be transported following root uptake. This appears to be the case for lead,$^{13} \operatorname{copper}^{19}$ and vanadium. ${ }^{20}$ However, other equally important elements such as cadmium ${ }^{21}$ and mercury ${ }^{22}$ appear readily mobile subsequent to root uptake. From the above it is clear that the factors which regulate the incidence and quantity of root-absorbed heavy metals in the lumina of xylem elements require further investigation. Until our knowledge of these factors is considerably greater, it is impossible to predict the levels of metals arriving in woody tissues from the soil.

\section{Foliar uptake}

Foliar uptake of heavy metals is little understood at present Information available on foliar metal levels in polluted areas demonstrates the high concentrations frequently encountered (e.g. Vamerali et al. ${ }^{23}$ ). Almost the entire range of environrnentally important trace metals has been detected in rainfall, ${ }^{24}$ but the relationship between these levels of deposition, levels in the leaves and in other plant parts is at present unknown. The main problem in the clarification of foliar uptake is the physical state in which the heavy metal arrives at the leaf surface. As an example, lead is most commonly encountered in a particular form, predominantly occurring in particles of $10 \mu$ diameter or less. How lead arriving in this form enters the tissues of the leaf is not known, as no information is available concerning lead release from particulates.

Uptake of soluble heavy metal salts by leaves has been investigated, most notably for those metals which function as essential micronutrients. Uptake studies on copper ${ }^{19,25}$ and zinc ${ }^{25}$ have demonstrated the relative ease with which solutions of these metals will penetrate leaf cuticles. Riederer and Schneider ${ }^{26}$ and Schönherr ${ }^{27}$ have demonstrated ready cuticular penetration of solutions containing $51 \mathrm{cr}$. It seems safe to conclude that most heavy metals will penetrate leaf cuticles when present in a soluble form, but the steps between particulate deposition and solubilisation await investigation.

\section{Direct stem uptake}

Lepp and Dollard ${ }^{28}$ have experimentally demonstrated direct stem uptake of soluble $210 \mathrm{pb}$. These workers showed that slow, probably apoplastic, lateral movement of $210 \mathrm{pb}$ took place in stem segments of a range of deciduous tree species. This took place in both dormant and reactivating segments. Direct stem uptake may be important in deciduous trees, where the exposed stem surfaces will form the main deposition sites for atmospheric heavy metals during the winter months. Direct detection of lead-containing particles on bark surfaces has been reported, ${ }^{29}$ but the question of solubilisation of these particles remains to be answered. Metal deposition on stem surfaces may be regulated by stem flow, which act either as a source of metals from upper parts of the tree, or as a metal-removing factor. Metal levels in relation to stem flow do not appear to have been investigated. In conclusion, the quantification of metal uptake from either atmospheric or soil sources remains a difficult problem until more information is available on the factors which regulate metal entry.

\section{Transportation from uptake sites}

Having specified the major sites available for heavy metal uptake by plants, some consideration must be given to the transport processes involved in the movement of these elements within the plant, and, more specifically, to woody tissue.

\section{Root absorbed heavy metals}

All substances absorbed from soil water via the root system are eventually distributed within the plant via the transpiration stream. Substances are transported within this continuous column of water along the lumina of the xylem elements, and eventually reach the leaves. Such transport is a passive process, and any removal of substances from the transpiration stream will take place by lateral movement from the conducting elements to adjacent, non-conducting tissues. The transpiration stream is the main re-distributive agency not only for root absorbed anions and cations, but also for organic nitrogenous compounds (mainly amino acids), organic acids, some carbohydrates and growth regulators such as gibberellins and cytokinins. The regulation of the concentration of the various components is a reflection of the edaphic status of the medium in 
which the plant is located, and in the biosynthetic activity of cells in the root and stem. The rate of transport of the milieu is regulated by evaporation at the leaf surface, which is ultimately controlled by the responses of the stomatal guard cells to a range of fluctuating environmental parameters. Whilst the actual mechanism of transport is straightforward, the rate of transport and composition of the transpiration stream are both capable of considerable variation during a single ring-forming season.

In view of the simplicity of the system, analysis of xylem sap has proved to be a straightforward process. As a result of this, information on metal transport within the transpiration stream is readily available. Recent reviews ${ }^{30,31}$ presented a summary of present knowledge of metal transport. Most metals are transported in a complexed form, and the existence of free metal ions in xylem sap appears highly unlikely. The existence of various metal ligands has been demonstrated, and our present knowledge of the nature of these complexes is detailed below.

Copper: Anionic complexes possessing similar electrophoretic characteristics can be identified in both root pressings and xylem exudate. This anionic complex appears to be common to several plant species. Although the organic ligand has not been identified, a study of copper chemistry is indicative of the involvement of an amino acid. ${ }^{19}$

Nickel: Only anionic nickel complexes have been detected in xylem sap. As the chemistry of nickel is closely related to that of copper, it has been assumed that the nickel ligand is made with one or more amino acids. ${ }^{32}$

Chromium: Reis et al. ${ }^{33}$ report the presence of $\mathrm{Cr}_{2} \mathrm{O}_{4}$-ions in the xylem sap of the shrub Leptospermum scoparium. Subsequent studies have not revealed the presence of other complexes, so $\mathrm{Cr}$ may be transported in a relatively simple chemical form.

Zinc: Early evidence indicated that $\mathrm{Zn}$ was not bound to stable ligands, but was present in xylem sap in a weakly cathodic form. Work by Gupta et al. ${ }^{34}$ has indicated that this may be an artefact, for electrophoretic studies have indicated that untreated xylem exudate revealed the presence of a slightly anodic zinc ligand. However, the organic compound involved remains unidentified. Information on the transport forms of other important heavy metals is non-existent. Investigation of the transport forms taken by cadmium, lead, mercury and vanadium is desirable, together with identification of their organic ligands.

\section{Foliar-absorbed heavy metals}

Metals present within leaves have only one major pathway for subsequent rapid and large-scale export. This is the phloem, and investigations of metal transport in this tissue present much greater problems than comparable xylem studies. The major barrier to metal transport in the phloem is phloem loading, a highly specific, metabolically-dependent process. If this loading barrier can be overcome, one may assume that an essentially foreign substance, such as a heavy metal, may be swept along the transport conduits with the source-sink flow of organic assimilates. It should be mentioned that large quantities of potential organic ligands can be found in sieve elements $^{35}$ and that the amino acids are subject to marked seasonal variation.

A summary of our meagre knowledge of phloem transport of heavy metals is given by Stephan and Scholz. ${ }^{36}$ Apart from the detection of copper and zinc in yucca phloem exudates, ${ }^{37}$ and a circumstantial account of the gross redistribution of foliar-applied copper in almond trees, ${ }^{38}$ little is known. Further investigations may reveal that some heavy metals are phloem mobile. For instance, foliar-applied mercury appears to be rapidly re-distributed in the plant, and at some stage in this process must have been present in the phloem. ${ }^{39,40}$

Lateral movement of both organic and inorganic substances from phloem to xylem is well known. ${ }^{41}$ Thus, if a heavy metal is exported from a contaminated leaf via the sieve elements, it possesses the potential for subsequent lateral movement into, and re-distribution within, the xylem. Unloading processes associated with sieve elements have received little attention, but studies on organic assimilates have indicated that unloading is not confined to any specific site, but may take place over the entire length of the transport conduits. ${ }^{41}$

\section{Direct stem uptake}

This process is subject to far fewer limiting factors than the pathways from roots or leaves. Experiments by Osabor et al. ${ }^{42}$ have indicated that, for lead, this process is slow and probably nonmetabolic. A sequential series of experiments performed on stem segments in various stages of cambial re-activation suggested that living cambial tissue is non-essential for transport from bark to wood.

\section{Behaviour of heavy metals in wood}

Consideration must be given to a series of problems directly related to metal deposition in an annual growth ring. These are the occurrence of potential organic ligands in the xylem sap, and the ways in which these vary in quantity over a ring-forming season, the binding of heavy metals to xylem tissue, and the relationship between wood structure, transpiration pathways and deposition patterns of heavy metals.

\section{Occurrence and formation of ligands}

It has been demonstrated that considerable seasonal changes may occur in the total nitrogen and sugar content of the xylem sap of rosaceous trees. ${ }^{31,43}$ As the bulk of organic nitrogen present in xylem sap is in the form of amino acids, this clearly represents an important, season-dependent variation in the occurrence of potential ligands. In another study ${ }^{44}$ found that levels of amino nitrogen increased rapidly to a maximum at the onset of flowering, and showed an equally sharp decline in the immediate post-blooming period. Conversely, sugar levels decline to a minimum during flowering, and exhibit a subsequent rise in the following period of fruit development.

As a result of successive studies accomplished by Bangerth ${ }^{45}$ we possess a detailed account of the major amino acid components of xylem exudate of apple, in the period of cambial re-activation. These workers identified two major amino acids-arginine and asparagine-which, together, comprise over $75 \%$ of total amino acids in the xylem during this period. A survey of stability constants reveals that arginine has been shown to form ligands with $\mathrm{Cd}, \mathrm{Cu}, \mathrm{Ni}, \mathrm{Pb}$, and $\mathrm{Zn}$, and asparagine complexes with $\mathrm{Cd}, \mathrm{Cu}, \mathrm{Ni}$ and $\mathrm{Zn}$. The stability constants of these various ligands are well below those measured for EDTA complexes of the various metal ions. Stability constants (K) are a measure of the relative stability of, in this case, metal ligand complexes. If the value for $\mathrm{K}$ is large, the more stable the complex formed, and the less ligand required for complex formation. Generally speaking, metal EDTA complexes are the most stable, and, as such, possess the highest stability constants. 
Other possible organic ligands identified include organic acids and, from the work of Gupta et al..$^{34}$ it would appear that citric acid may be an important ligand, not only for $\mathrm{Fe}$, but for other metals as well. The occurrence of this, together with other organic and ketoacids, in the xylem has been reported. ${ }^{46}$ Table 1 details the stability constants for a range of metals with EDTA, arginine, asparagine and citric acid. From this it can be seen that stability constants vary for the same metal with different potential ligands, but all potential complexes are considerably less stable than the metal-EDTA complexes. These variations in stability may prove to be a limiting factor in metal transport, especially if ligand supplies are limited. If the heavy metals are transported in the xylem sap bound to various organic ligands, then the potential for metal transport will clearly be dependent upon ligand availability. One may foresee a situation where trees growing in situations subjected to multi-element pollution may only selectively transport those metals which most readily combine with available ligands. In this case, subsequent patterns of heavy metal deposition in annual growth rings may only reveal the presence of more readily transportable metals. All values for fully saturated complexes, between 20 and $25^{\circ} \mathrm{C}$. Source--Stability Constants of Metal-ion Complexes. Data from Ref. ${ }^{47-49}$

Table I The stability constants of heavy metals with a range of organic ligands

\begin{tabular}{lllll}
\hline Element & Arginine & 4 Sparagine & Citric Acid & ED TA \\
\hline Cadmium & 3.18 & 6.8 & 4.2 & 17.5 \\
Copper & 6.42 & 6.35 & 5.2 & 18.8 \\
Nickel & 3.08 & 4.38 & 5.11 & 19 \\
Lead & 3.36 & - & 5.74 & 18.1 \\
Zinc & 3.93 & 8.7 & 4.9 & 15.9 \\
\hline
\end{tabular}

\section{Deposition of metals in wood}

In considering the possible processes of metal deposition in woody tissue, we must first know something of the chemical composition of wood itself. The cell walls of xylem vessels are made up of cellulose, hemicellulose and lignin..$^{50}$ The proportion of lignin to polysaccharides in the fully differentiated vessel wall is 60:100, but this may vary between species. However, newly differentiated xylem elements contain no lignin ${ }^{51}$ lignin formation only occurring as the vessel ages. Thus, newly formed xylem elements have walls composed of polysaccharides and pectic substances only, in fact not dissimilar to the walls of other plant cells.

Regarding the immobilisation of heavy metals in cell walls, we have some detailed information on types of cell involved, and possible mechanisms. Many metal-tolerant plants have been shown to accumulate high concentrations of particular elements in their cell walls, ${ }^{52,53}$ but evidence for this comes primarily from observations on living root tissues. Nickel localisation in shoot tissue of the nickeltolerant Alyssum bertolinii Desv., has been demonstrated by Marmiroli et al..$^{54}$ nickel being accumulated in non-living sclerenchyma, located between the vascular bundles.

The mechanism by which metals may be deposited in cell walls has recently been investigated by Kato and Nevin ${ }^{55}$ and Zhong and Ye. ${ }^{56}$ These workers used a histochemical technique to observe stages in the immobilisation of root-applied lead in Zea. Their studies revealed that lead could be immobilised in cell walls, and that the dictyosome, actively participating in the synthesis of new cell-wall material, immobilised the lead. These results were obtained with living cells, but may be relevant to metal binding in xylem tissue. When xylem vessels are differentiated, they do not possess a lignified wall. In fact the wall structure and composition will be similar to that of a parenchyma cell. In addition, the newly formed elements are in very close proximity to the vascular cambium, and as lead will readily pass through the cambial tissue ${ }^{57}$ it is conceivable that some proportion of bark-deposited lead may find its way into the walls of the newly differentiated xylem vessels. Also, lead from the transpiration stream in adjacent early-wood vessels, which will be functional, may find its way into the walls of the young elements and be deposited in this way.

A range of heavy metals can be deposited in wood, as analysis of wood from polluted and urban areas shows. ${ }^{58}$ However, the rate at which binding may occur, and the relationship of the transport form of the metal in question to binding potential has, as yet, received little attention. An experimental approach to this problem has been made by Stejskalová et al. ${ }^{59}$ to investigate the binding of free and complexed lead in xylem tissue of sycamore (Acer pseudoplatanus L.). This involved the use of a perfusion technique, originally developed by Mizuno and Katou. ${ }^{60}$ Short stem segments were initially perfused with lead nitrate solutions, labelled with $210 \mathrm{pb}$. Perfused segments were 'incubated' for various time periods, then re-perfused with solutions of unlabelled lead nitrate, which would exchange with any unbound $210 \mathrm{pb}$ present in the xylem. Results from these experiments showed a steady increase in the quantity of lead bound to xylem tissue, over a time range from 1 to $36 \mathrm{~h}$. Similar experiments using a labelled lead ligand (210pb glycine) revealed an analogous trend in lead binding, but at a considerably reduced level. From these results, it is evident that free lead ions bind more rapidly to wood than lead ligands, but under natural conditions it is more likely that a lead ligand is the normal xylem transport form. At present, the situation with regard to other elements is not known but, from the evidence gained using lead, it is possible that the ligands of the various elements may bind to xylem tissue less readily than the free ions. The location of binding sites is also unknown, but it may well be that these sites are not element specific, and in cases where several elements are present in xylem sap, competition for binding sites may occur.

\section{Redial movement within the wood}

Little is known about the extent to which radial transport of metals within wood occurs. The existence of xylem rays is well known, as also is the fact that ray sizes vary between tree species. As areas of living cells within the dead xylem elements, these rays represent possible channels of mobility within the wood. ${ }^{61}$ Climent et al. ${ }^{62}$ and Pieniążek and Sadowski ${ }^{63}$ have postulated that xylem rays may form an excretory pathway for potentially toxic metabolites and foreign substances, away from the cambial zone to the heartwood. They presented convincing evidence for the operation of such a pathway for heavy metals. If transport along the rays is via living cells, then circumstances similar to those described by Johnson ${ }^{64}$ and Secchi et al. ${ }^{65}$ could be in operation, with immobilisation of, for instance, lead, in the cell walls of the ray cells. As new ray cells are formed each year, lead build-up in the rays could also be dependent upon ambient levels, and, for metals to which living cells react in a similar manner, ray transport may be negligible.

\section{Pathway of water movement in relation to metal de- position}

Two distinct types of wood structure exist in trees, ring-porous and 
diffuse porous. Trees with the former structure possess long xylem elements, with large lumina, whilst the latter have shorter, narrower xylem vessels with more cross walls. Some deciduous trees are ringporous, notably oak (Quercus), elm (Ulmus) and ash (Fraxinus). Other deciduous trees such as sycamore (Acer), willow (Salix) and poplar (Populus) are diffuse-porous, along with all coniferous trees.

In ring-porous trees, water movement takes place through the current year's early wood vessels, which tend to function as a pipe connecting one particular part of the root system to one particular portion of the crown, ${ }^{66}$ and the pitch of this spiral may alter from year to year. Clearly, then, the pattern of water--and hence metal movement in the wood of diffuse porous trees--presents a more complex picture than in ring-porous species. In view of this, caution should be observed in interpreting data obtained from analysis of diffuse-porous species. It is of interest to note that in their survey, Takahashi et al. ${ }^{67}$ used both ring- and diffuse-porous species, whereas Christman et al. ${ }^{68}$ and Kames et al. ${ }^{69}$ used exclusively ring-porous species. The rate at which the transpiration stream moves through the xylem vessels also deserves consideration. Transpiration rate is dependent upon the microclimate surrounding the major sites of water loss. Therefore, as the microclimate around the leaf surface changes, the rate of transpiration will change. What these alterations in the rate of movement of the water column carrying the metal mean in terms of metal deposition patterns is not known. If the rate of transpiration is rapid, there is an increased potential for metal uptake via the roots, but what effect the movement of the transpiration stream has on the absolute quantity of metal bound to wood is not known. Similar questions must be posed with regard to the possibility of metal gradients occurring within the xylem, which could arise as a result of abstraction of metals during upward flow of the transpiration stream. Such an occurrence is possible; as the perfusion studies ${ }^{70-73}$ which have been demonstrated, and suggests that standardisation of sampling height is necessary in comparative studies.

\section{Conclusion}

Tree-ring analysis provides a useful means of assessing many internal and external events in the life history of a tree. Its techniques have been standardised and are used on a worldwide basis. At first sight, it would appear to be an ideal means of assessing heavy metal pollution histories, by means of precise chemical analysis of single, or groups of, annual growth rings. However, by considering the means by which heavy metals arrive in woody tissues, and what little information we possess on their behaviour within wood, the initial optimistic view may be somewhat tempered. Many factors may influence the absolute amounts of heavy metals present in woody tissues, including those which affect their uptake by the tree, from soil or atmosphere, the transport form taken by the metal within the plant, and the rate at which this may bind to xylem tissue. Evidence has also been presented which shows that lateral exchange of heavy metals may occur between bark and wood, which may also be an important factor in determining heavy metal levels in an annual growth ring. However, at this stage, we are unable to quantify the magnitude of any of the barriers in respect to heavy metal levels present within annual growth rings.

The following areas require investigation: transport form of metals in xylem, and the nature and seasonal variation of their organic ligands; the rate and magnitude of metal binding to xylem tissue in relation to transport form, and rate of transport; and the presence or absence of appreciable lateral metal re-distribution via the xylem rays. Finally, we must have some indication of the way in which metal levels in annual growth rings reflect the biologically-available proportion of heavy metals within the particular location where the tree is sited. It is only when we have some ways towards providing answers to these questions that a true and objective perspective may be placed on the potential of tree-ring analysis for dating heavy metal pollution histories.

\section{Recommendation}

Through this wide survey, we conclude that still further research must be done in order to study the uptake of metals from the roots to the shoots along and also to establish the possible transformation mechanisms for metal tolerance of the plant and to evaluate the effects of the individual heavy metals as well as the combined effects of different levels on soil quality and relative uptake to the edible plant species. In addition, more studies are also suggested to check the similarity in elemental content between toxic-bearing particles on trees and some of the compounds emitted from industry by developing a suitable modelling design that can separate the climatic and anthropogenic effects on the tree-ring.

\section{Acknowledgements}

None.

\section{Conflict of interest}

Authors have declared that no competing interests exist.

\section{References}

1. Shotyk W, Blaser P, Grünig A, et al. A new approach for quantifying cumulative, anthropogenic, atmospheric lead deposition using peat cores from bogs: $\mathrm{Pb}$ in eight Swiss peat bog profiles. Science of The Total Environment. 2000;248(1-3):281-295.

2. Sharma M, Maheshwari M, Morisawa S. Dietary and inhalation intake of lead and estimation of blood lead levels in adults and children in Kanpur, India. Risk Analysis. 2005;25(6):1573-1588.

3. Brink LL, Talbott EO, Sharma RK, et al. Do US ambient air lead levels have a significant impact on childhood blood lead levels: results of a national study. Journal of Environmental and Public Health. 2013;2013:278042.

4. Méndez M, Battocletti A, Sosa A, et al. Blood lead levels and potential sources of lead exposure among children in Montevideo, Uruguay. Toxicology Letters. 2016;259:S170.

5. Miquel SE, Bungartz F. Snails found among herbarium specimens of Galapagos lichens and bryophytes, with the description of Scolodonta rinae (Gastropoda: Scolodontidae), a new species of carnivorous micro-mollusk. Archiv für Molluskenkunde International Journal of Malacology. 2017;146(1):173-186.

6. Jones AMP, Shukla MR, Biswas GCG, et al. Protoplast-to-plant regeneration of American elm (Ulmus americana). Protoplasma. 2014;252(3):925-931.

7. Napierała-Filipiak A, Filipiak M, Łakomy P, et al. Changes in elm (U1mus) populations of mid-western Poland during the past 35 years. Dendrobiology. 2016;76:145-156.

8. Crispino LCBC, de Lima MC. Expedição norte-americana e iconografia inédita de Sobral em 1919. Revista Brasileira de Ensino de Física. 2018;40(1). 
9. Jaskowska-Lemańska J, Wałach D. Impact of the direction of non-destructive test with respect to the annual growth rings of pine wood. Procedia Engineering. 2016;161:925-930.

10. Racko V, Misikova O, Cunderlik I, et al. Indentation of juvenile annual growth rings and their impact on morphology of wood cells. Key Engineering Materials. 2016;688:175-181.

11. Bellis DJ, Satake K, Noda M, et al. Evaluation of the historical records of lead pollution in the annual growth rings and bark pockets of a 250-year-old Quercus crispula in Nikko, Japan. Science of The Total Environment. 2002;295(1-3):91-100.

12. Kosobrukhov A, Knyazeva I, Mudrik V. Plantago major plants responses to increase content of lead in soil: Growth and photosynthesis Plant Growth Regulation. 2004;42(2):145-151.

13. Łukowski A, Wiater J. The content and solubility of lead in arable soils of the Podlasie Province (eastern Poland). Soil Science Annual. 2016;67(4)

14. Yeston J. CO takes the lead to make $\beta$-lactam rings. Science. 2016;354(6314):843-845.

15. Szopa PS, McGuinness EAJR, Pierce JO. Distribution of lead within the xylem of trees exposed to airborne lead compounds. Wood Science and Technology. 1973;6:72-77.

16. Georgiev P, Groudev S, Spasova I, et al. Remediation of a grey fores soil contaminated with heavy metals by means of leaching at acidic $\mathrm{pH}$ Journal of Soils and Sediments. 2015;16(4):1288-1299.

17. Najafi S, Jalali M. Effect of heavy metals on $\mathrm{pH}$ buffering capacity and solubility of $\mathrm{Ca}, \mathrm{Mg}, \mathrm{K}$, and $\mathrm{P}$ in non-spiked and heavy metal-spiked soils. Environmental Monitoring and Assessment. 2016;188(6):342

18. Cui X, Sun X, Hu P, et al. Concentrations of heavy metals in suburban horticultural soils and their uptake by artemisia selengensis. Pedosphere. $2015 ; 25(6): 878-887$.

19. Azeez O, Adesanwo O, Adepetu A. Effect of Copper $(\mathrm{Cu})$ application on soil available nutrients and uptake. African Journal of Agricultural Research. 2015;10(5):359-364.

20. Lepp NW, Morrell BG, Phipps DA. Vanadium absorption by plants the uptake of vanadium by excised barley roots (Hordeum Vulgare c.v. Maris Mink). Inorganica Chimica Acta. 1983;79:228-229.

21. Sterckeman T, Redjala T, Morel JL. Influence of exposure solution composition and of plant cadmium content on root cadmium short-term uptake. Environmental and Experimental Botany. 2011;74:131-139.

22. Harris-Hellal J, Grimaldi M, Garnier-Zarli E, et al. Mercury mobilization by chemical and microbial iron oxide reduction in soils of French Guyana. Biogeochemistry. 2010;103(1-3):223-234.

23. Vamerali T, Bandiera M, Hartley W, et al. Assisted phytoremediation of mixed metal(loid)-polluted pyrite waste: Effects of foliar and substrate IBA application on fodder radish. Chemosphere. 2011;84(2):213-219.

24. Munné-Bosch S. Direct foliar absorption of rainfall water and its biological significance in dryland ecosystems. Journal of Arid Environments. 2010;74(3):417-418

25. Nwaogu LA Iwueke AV, Igwe CU, et al. Heavy metal pollution mediated oxidative stress in amaranthus hybridus leaves. International Journal of Biochemistry Research \& Review. 2012;2(2):78-86.

26. Riederer M, Schneider G. The effect of the environment on the permeability and composition of Citrus leaf cuticles. II. Composition of soluble cuticular lipids and correlation with transport properties. Planta. 1990;180(2):154-165.

27. Schönherr J. Foliar nutriton using inorganic salts: laws of culticular penetration. Acta Horticulturae. 2002;594:77-84.
28. Lepp NW, Dollard GJ. Studies on lateral movement of $210 \mathrm{~Pb}$ in woody stems. Oecologia. 1974;16(2):179-184.

29. Koslow EE, Smith WH, Staskawicz BJ. Lead-containing particles on urban leaf surfaces. Environmental Science \& Technology. 1977;11(10):1019-1021.

30. Barbour MM, Farquhar GD, Buckley TN. Leaf water stable isotopes and water transport outside the xylem. Plant, Cell \& Environment. 2016;40(6):914-920.

31. Losso A, Nardini A, Dämon B, et al. Xylem sap chemistry: seasona changes in timberline conifers Pinus cembra, Picea abies, and Larix decidua. Biologia Plantarum. 2017;61(295):1-9.

32. Gasparics T, Mihucz VG, Tatár E, et al. Hyphenated technique for investigation of nickel complexation by citric acid in xylem sap of cucumber plants. Microchemical Journal. 2002;73(1-2):89-98.

33. Reis FVP, Gutiérrez-Ginés MJ, Smith CMS, et al. Mānuka (Leptospermum scoparium) roots forage biosolids in low fertility soil. Environmental and Experimental Botany. 2017;133:151-158.

34. Gupta N, Ram H, Kumar B. Mechanism of Zinc absorption in plants uptake, transport, translocation and accumulation. Reviews in Environmental Science and Bio/Technology. 2016;15(1):89-109.

35. Landén A, Hall POJ. Seasonal variation of dissolved and adsorbed amino acids and ammonium in a near-shore marine sediment. Marine Ecology Progress Series. 1998;170:67-84.

36. Stephan UW, Scholz G. Nicotianamine: mediator of transport of iron and heavy metals in the phloem? Physiologia Plantarum. 1993;88(3):522-529.

37. Wolterbeek B, Die JV. The contents of some hitherto not reported trace elements in phloem exudate from yucca flaccid haw., determination by means of non-destructive neutron activation analysis. Acta Botanica Neerlandica. 1980;29(4):307-309.

38. Kester DE, Uriu K, Aldrich T. Copper deficiency in almonds and its response to treatment. Proceedings of the Society for Horticultural Science. 1961;77:307-309.

39. Ross RG, Stewart DKR. Mercury resources in potatoes in relation to foliar sprays of phenyl mercury chloride. Canadian Journal of Plant Science. 1964;44(2):123-125.

40. Ericksen J, Gustin M. Foliar exchange of mercury as a function of soil and air mercury concentrations. Science of The Total Environment. 2004;324(1-3):271-279.

41. Wan J, Cabanillas DG, Zheng H, et al. Turnip mosaic virus moves systemically through both phloem and xylem as membrane-associated complexes. Plant Physiology. 2015;167(4):1374-1388.

42. Osabor V, Etiuma R, Ntinya M. Chemical profile of leaves and roots of miracle fruit (synsepalum dulcificum). American Chemical Science Journal. 2016;12(1):1-8.

43. Masaki N, Okamoto H. Correlation between the seasonal changes in electrogenic activity across root xylem/symplast interface, sapflow rate and xylem pressure in field trees (Diospyros kaki). Trees. 2007;12(4):433-442.

44. Zakeri H, Bueckert R. Post-flowering biomass and nitrogen accumulation of lentil substantially contributes to pod production. Crop Science. 2015;55(1):411

45. Bangerth KF. A novel, repeatable, and non-destructive method to collect root xylem exudate from mature apple trees in an orchard and to compare its constituents with shoot exudate. The Journal of Horticultural Science and Biotechnology. 2008;83(3):374-380.

46. Barbour MM, Farquhar GD, Buckley TN. Leaf water stable isotopes and water transport outside the xylem. Plant, Cell \& Environment. 2016;40(6):914-920. 
47. Palma LD, Mecozzi R. Heavy metals mobilization from harbour sediments using EDTA and citric acid as chelating agents. Journal of Hazardous Materials. 2007;147(3):768-775.

48. Muhammad D, Chen F, Zhao J, et al. Comparison of EDTA- and citric acid-enhanced phytoextraction of heavy metals in artificially metal contaminated soil by typha angustifolia. International Journal of Phytoremediation. 2009;11(6):558-574.

49. Wei M, Chen JJ, Liu YS. The combination of $\mathrm{Na}_{2}$ EDTA and reducing organic acid on remediation of soil contaminated by heavy metals. Key Engineering Materials. 2017;744:531-535.

50. Zhang X, Chen S, Xu F. Combining Raman Imaging and Multivariate Analysis to Visualize Lignin, Cellulose, and Hemicellulose in the Plant Cell Wall. Journal of Visualized Experiments. 2017;124:e55910.

51. Fukushima K, Terashima N. Heterogeneity in formation of lignin. XIV. formation and structure of lignin in differentiating Xylem of Ginkgo biloba. Journal of Visualized Experiments. 1991;45(2):87-94.

52. Farago ME. Metal tolerant plants. Coordination Chemistry Reviews. 1981;36(2):155-182.

53. Mutia TM, Fridriksson T, Jónsdóttir IS. Concentrations of sulphur and trace elements in semi-arid soils and plants in relation to geothermal power plants at Olkaria, Kenya. Geothermics. 2016;61:149-159.

54. Marmiroli M, Gonnelli C, Maestri E, et al. Localisation of nickel and mineral nutrients $\mathrm{Ca}, \mathrm{K}, \mathrm{Fe}, \mathrm{Mg}$ by Scanning Electron Microscopy microanalysis in tissues of the nickel-hyperaccumulator Alyssum bertolonii Desv. and the non-accumulator Alyssummontanum L. Plant Biosystems. 2004;138(3):231-243.

55. Kato Y, Nevins DJ. Structural characterization of a $(1 \rightarrow 4)-\beta$-D-galactan from cell walls of zea mays shoots. Journal of Applied Glycoscience. 2014;61(4):105-108.

56. Zhong R, Ye ZH. Secondary cell walls: biosynthesis, patterned deposition and transcriptional regulation. Plant and Cell Physiology. 2014;56(2):195-214.

57. Wilczek A, Wloch W, Kojs P, et al. Correlation of intrusive growth of cambial initials to rearrangement of rays in the vascular cambium. IAWA Journal. 2011;32(3):313-331.

58. Witek-Krowiak A. Application of beech sawdust for removal of heavy metals from water: biosorption and desorption studies. European Journal of Wood and Wood Products. 2013;71(2):227-236.

59. Stejskalová J, Kupka I, Miltner S. Effect of gibberellic acid on germination capacity and emergence rate of Sycamore maple (Acerpseudoplatanus L.) seeds. Journal of Forest Science. 2016;61(8):325-331.
60. Mizuno A, Katou K. The characteristics of the adjustment in the $\mathrm{pH}$ of the xylem exudate of segments of vigna hypocotyls during xylem perfusion. Plant and Cell Physiology. 1991;32(3):403-408.

61. Donnelly JR, Shane JB, Schaberg PG. Lead mobility within the xylem of red spruce seedlings: implications for the development of pollution histories. Journal of Environment Quality. 1990;19(2):1-4.

62. Climent J, Gil L, Pardos JA. Xylem anatomical traits related to resinous heartwood formation in Pinus canariensis Sm. Trees. 1998;12(3):139-145.

63. Pieniążek J, Sadowski M. Hormonal control of cambial activity and xylem differentiation in apple shoots. Acta Agrobotanica. 1998;21:113-129.

64. Johnson RPC. Can cell walls bending round xylem vessels control water flow? Planta. 1977;136(3):187-194.

65. Secchi F, Pagliarani C, Zwieniecki MA. The functional role of xylem parenchyma cells and aquaporins during recovery from severe water stress. Plant, Cell \& Environment. 2016;40(6):858-871.

66. Kitin P, Funada R. Earlywood vessels in ring-porous trees become functional for water transport after bud burst and before the maturation of the current-year leaves. IAWA Journal. 2016;37(2):315-331.

67. Takahashi S, Okada N, Nobuchi T. Relationship between the timing of vessel formation and leaf phenology in ten ring-porous and diffuse-porous deciduous tree species. Ecological Research. 2013;28(4):615-624.

68. Christman MA, Sperry JS, Smith DD. Rare pits, large vessels and extreme vulnerability to cavitation in a ring-porous tree species. New Phytologist. 2011;193(3):713-720.

69. Kames S, Tardif JC, Bergeron Y. Continuous early wood vessels chronologies in floodplain ring-porous species can improve dendrohydrological reconstructions of spring high flows and flood levels. Journal of Hydrology. 2016;534:377-389.

70. Uddin J, Smith R, Hancock N, et al. Evaluation of sap flow sensors to measure the transpiration rate of plants during canopy wetting and drying. Journal of Agricultural Studies. 2014;2(2):105.

71. Brüggenwirth M, Winkler A, Knoche M. Xylem, phloem, and transpiration flows in developing sweet cherry fruit. Trees. 2016;30(5):1821-1830.

72. Secchi F, Zwieniecki MA. Accumulation of sugars in the xylem apoplast observed under water stress conditions is controlled by xylem $\mathrm{pH}$. Plant, Cell \& Environment. 2016;39(11):2350-2360.

73. Vogel T, Votrubova J, Dohnal M, et al. A simple representation of plant water storage effects in coupled soil water flow and transpiration stream modeling. Vadose Zone Journal. 2017;16(5):1-10. 